Preprints of the

Max Planck Institute for

Research on Collective Goods

Bonn 2009/39

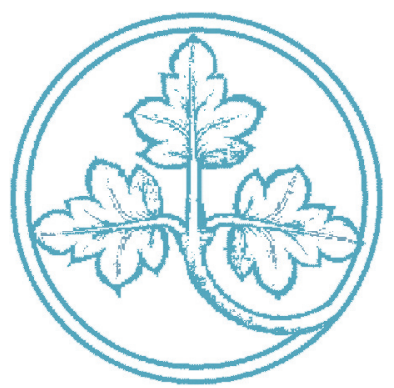

The Reception of

International Law by Constitutional Courts through the Prism of Legitimacy

Niels Petersen

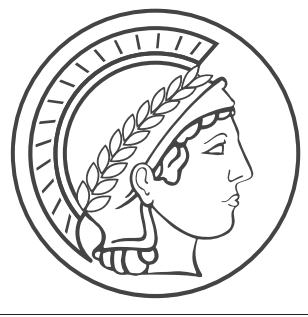




\title{
The Reception of International Law by Constitutional Courts through the Prism of Legitimacy
}

\author{
Niels Petersen
}

November 2009, revised January 2011 


\title{
THE RECEPTION OF INTERNATIONAL LAW BY Constitutional Courts THROUgh the Prism of LEGITIMACY
}

\author{
by Niels Petersen ${ }^{*}$
}

\begin{abstract}
This contribution seeks to shed new light onto the classification of legal orders with respect to the domestic effect of international law. Traditional theory distinguishes between monist and dualist systems, those that accept the primacy of international law over domestic law, and those that do not attribute direct effect to international law in the domestic legal order. We will examine three different lines of constitutional jurisprudence on the effect of decisions of international authorities in the domestic order. It is maintained that all courts dealing with the domestic effect of international secondary law ultimately face questions of legitimacy of the external decision-making procedure. We will identify three strategies to cope with this challenge and argue that it is more appropriate to consider the relationship of a national legal order to international law through the prism of how its constitutional court approaches the governance issue than to refer to the traditional monism-dualism-dichotomy.
\end{abstract}

\section{Introduction}

One of the big debates of international law scholarship of the last century centered on the relationship between international law and domestic law. ${ }^{1}$ Today, there seems to be agreement that it is not possible to give one abstract, universal answer to the question. The effect of international law rather depends on how the conflict is solved by each domestic legal order. ${ }^{2}$ However, the question has regained attention. Two recent decisions of constitutional courts have caused a great stir in legal scholarship. In its Medellin decision, the U.S. Supreme Court had to deal with the effect of decisions of the International Court of Justice in the U.S. legal order. ${ }^{3}$ Equally, the European Court of Justice had to decide in the Kadi judgment on whether Resolutions of the U.N. Security Council are absolutely

* Dr. iur. (Frankfurt), M.A. (Columbia), Senior Research Fellow at the Max Planck Institute for Research on Collective Goods, Bonn. I am indebted to Christoph Engel, Matthias Goldmann, Isabelle Ley, Indra Spiecker gen. Döhmann, Ingo Venzke and Dorian Warren as well as to the participants of the workshop on the normativity and legitimacy of political systems at the Helmut-Schmidt University in Hamburg and the workshop on current issues in international law at the Max Planck Institute for Comparative Public Law and International Law in Heidelberg for valuable and thoughtful comments on earlier drafts of the paper.

1 See the groundbreaking contributions of Heinrich Triepel, Völkerrecht und Landesrecht (Leipzig: Hirschfeldt, 1899) (taking a dualistic position, according to which international law and domestic law are separate legal orders) and Hans Kelsen, Das Problem der Souveränität und die Theorie des Völkerrechts (Tübingen: Mohr, 1920) (according to whom international law and domestic law are part of a single monistic legal order).

2 Thomas Buergenthal, 'Self-Executing and Non-Self-Executing Treaties in National and International Law’ (1992) 235 RdC 303, 317.

3 Medellin v. Texas, 128 S Ct 1346 (2008). 
binding for the European legislator. ${ }^{4}$ Both courts came to the same result, rejecting the unconditional supremacy of international law.

Although similar in their result, the courts followed, as we will see, different rationales in Medellin and Kadi, which cannot be captured by the traditional distinction. The reason is that there is a new dimension to the debate. Traditionally, the question of domestic effect of international law referred to the application of customary international law or treaties to which the concerned state was a party. The political institutions of the respective state thus had a direct influence on the creation of the norm that was later to be applied in its domestic courts. There have recently, however, been developments that blur this traditional picture. Increasingly, new institutions are evolving on the international plane, which take decisions without many of the affected states being involved in the decisionmaking process. ${ }^{5}$ They exercise public authority unilaterally. ${ }^{6}$ This not only concerns administrative and legislative bodies, but also international courts and tribunals, which often play a pivotal role in deepening international integration. These forms of governance pose questions of legitimacy and thus represent new challenges to domestic courts that have to implement such international secondary law in the domestic legal order. ${ }^{7}$

The traditional monism/pluralism-divide assumes a hierarchy between competing legal orders. ${ }^{8}$ Under monism, the international order always trumps domestic norms, while, under dualism, the domestic order determines the rank of international law in the domestic setting. This description may be accurate if we have static legal orders, but it is inappropriate for dynamic régimes, which are shaped by decisions of courts and international institutions. Therefore, while conceptualizing the relationship of courts with competing jurisdiction, some scholars have recently departed from the hierarchical description of legal systems. They perceive the relation of different courts rather as one of cooperation ${ }^{9}$ or observe the emergence of a pluralistic order of jurisdictions. ${ }^{10}$

\footnotetext{
4 Joined Cases C-402/05 P and C-415/05 P, Yassin Abdullah Kadi, Al Barakaat International Foundation v. Council and Commission [2008] ECR I-6351.

5 See Benedict Kingsbury, Nico Krisch \& Richard Stewart, 'The Emergence of Global Administrative Law' (2005) 68.3 Law \& Contemporary Problems 15.

6 Armin von Bogdandy, Philipp Dann \& Matthias Goldmann, 'Developing the Publicness of Public International Law: Towards a Legal Framework for Global Governance Activities' (2008) 9 German LJ 1375,
} 1381.

The described developments are, of course, of a gradual, not a dichotomous, nature. It may thus be more appropriate to talk of thinner or thicker stratospheric layers than of distinct eras. See Joseph H.H. Weiler, 'The Geology of International Law - Governance, Democracy and Legitimacy' (2004) 64 Heidelberg JIL 547, 551.

8 Cf. Armin von Bogdandy, 'Pluralism, direct effect, and the ultimate say: On the relationship between international and domestic constitutional law' (2008) 6 I.CON 397, 397-98 (describing monism as pyramid).

9 See Franz C. Mayer, 'The European Constitution and the Courts' in Armin von Bogdandy \& Jürgen Bast (eds), Principles of European Constitutional Law (Oxford: Hart, 2006) 281; Lech Garlicki, 'Cooperation of Courts: The Role of supranational jurisdictions in Europe' (2008) 6 I.CON 509. See also Heiko Sauer, Jurisdiktionskonflikte in Mehrebenensystemen (Berlin: Springer, 2008) (proposing a system of mutual loyalty obligations as solution to conflicts of jurisdiction); Nikolaos Lavranos, 'Towards a Solange-Method between International Courts and Tribunals?' in Tomer Broude \& Yuval Shany (eds) The Shifting Allocation of Authority in International Law - Considering Sovereignty, Supremacy and Subsidiarity (Hart: Oxford, 2008) 217 (interpreting the Solange-jurisprudence as means of cooperation between courts).

10 See Janne Nijman \& André Nollkaemper, 'Beyond the Divide', in Janne Nijman \& André Nollkaemper (eds) New Perspectives on the Divide Between National and International Law (Oxford: Oxford University Press, 2007) 341, 359-60; Michael Rosenfeld, Rethinking constitutional ordering in an era of legal 
This contribution seeks to identify factors that explain the attitude of constitutional courts vis-à-vis international institutions. In two prominent contributions, Eyal Benvenisti has recently argued that courts act strategically in the application of international law in the domestic order. ${ }^{11}$ On the one hand, they try to shield domestic political branches from external pressure, on the other hand they want to ensure their own independence. In order to attain these goals, they often seek the cooperation with domestic courts from other legal systems and international tribunals. According to this reasoning, national courts thus often adhere to international decisions in order to establish "a united, coordinated judicial front." ${ }^{12}$ Benvenisti welcomes this development and argues that the cooperation of domestic courts in order to reduce the external pressures of globalization strengthens domestic democracy and increases the accountability of international regulatory institutions. ${ }^{13}$

Although we often observe instances of judicial cooperation, Benvenisti's account only tells part of the story. With regard to the adherence of national courts to international court decisions, there is evidence that courts not always follow the international courts in order to establish a coordinated judicial front. Instead, constitutional courts take different approaches in dealing with the implementation of international decisions. These differences cannot exclusively be explained by strategic considerations. It will be argued that the readiness to accept the direct effect of international decisions equally depends on the perceived legitimacy of the international authority. These legitimacy deliberations interact in different ways with strategic considerations. It will be shown that constitutional courts apply three different concepts of legitimacy when dealing with the implementation of decisions of international authorities in the domestic legal system.

In the following, I will first sketch the theoretical framework, highlighting that there are different standards for evaluating legitimacy. In order to exemplify the theoretical model, three lines of constitutional jurisprudence will be analyzed, each applying a different strategy for judging legitimacy. I will compare the jurisprudences of the U.S. Supreme Court, the European Court of Justice and the German Bundesverfassungsgericht. This analysis will show that the traditional accounts do not offer suitable explanations for the observed developments in constitutional jurisprudence. Therefore, a legitimacy-based categorization will be proposed, which should be more accurate in its explanations than the traditional monism-dualism-dichotomy.

\section{The exercise of international public authority and the problem of legitimacy}

The question of legitimacy is none that greatly concerns legal scholars in the domestic context. In democratic societies, we find an institutional setting that guarantees - through parliamentary legislation and judicial control - that the exercise of public authority is, in

and ideological pluralism (2008) 6 I.CON 415; Bogdandy, n 8 above; Nico Krisch, 'The Open Architecture of European Human Rights Law' (2008) 71 MLR 183.

11 Eyal Benvenisti, 'Reclaiming Democracy: The Strategic Uses of Foreign and International Law by National Courts' (2008) 102 AJIL 241; Eyal Benvenisti \& George W. Downs, 'National Courts, Domestic Demoracy, and the Evolution of International Law' (2009) 20 EJIL 59.

12 Benvenisti, n 11 above, 249.

13 Id., at 272-73; Eyal Benvenisti \& George W. Downs, 'Court Cooperation, Executive Accountability and Global Governance', 41 NYU JILP 931-958 (2009). 
general, legitimate. Legality can thus be considered as a presumption for legitimacy. ${ }^{14}$ This presumption has a rationalizing function: Courts are relieved of the need to control every sovereign act on its legitimacy. Because the system is assumed to be legitimate as a whole, they can concentrate on the formal control of legality. ${ }^{15}$ However, such a presumption cannot be made at the international level, where legal standards regarding legitimacy and the rule of law are not yet sufficiently developed..$^{16}$ Jurisprudence and legal scholarship thus cannot confine themselves to a formal control of the legality of international public authority. ${ }^{17}$ They rather have to take considerations of legitimacy into account. However, legitimacy is a contested concept that is subject to many prominent debates in legal and political science scholarship. There are basically three strategies to cope with the challenge of legitimizing public authority in the international arena, which shall be sketched in more detail in the following. ${ }^{18}$

\section{The state sovereignty paradigm and the illegitimacy of international authority}

The first strategy - we will call it the sovereignty paradigm - is to deny the legitimacy of international institutions at all. ${ }^{19}$ According to this position, legitimacy is inextricably linked to democracy, and democracy can only be exercised within the nation state because it presupposes the existence of a demos. The underlying idea is that nation state democracy is the only form of state that best preserves individual freedom and self-determination. Political self-determination requires the belonging to a specific political community, which is most often the nation state. Decisions that are taken outside this polity cannot be legitimate because either its citizens have not participated at all in the decision, or the latter has at least decisively been influenced by non-citizens. Authority is, at least partly, exercised by foreign actors. Under this reading of democracy, state sovereignty is thus not only a concept to protect statehood, but also to preserve democracy and the self-rule of political communities.

Every international decision-making procedure that does not require the consent of each individual state would consequently be illegitimate. Because of this illegitimacy, decisions of international institutions or international courts can never have a direct effect within the domestic legal order. They only become effective in the domestic sphere if they have been

14 Utz Schliesky, Souveränität und Legitimität von Herrschaftsgewalt (2004) 167.

15 Matthias Goldmann, 'Der Widerspenstigen Zähmung, oder: Netzwerke dogmatisch gedacht' in Sigrid Boysen et al. (eds) Netzwerke (Baden-Baden: Nomos, 2007) 225, 234.

16 See Mattias Kumm, 'Democratic Constitutionalism Encounters International Law: Terms of Engagement' in Sujit Choudhry (ed) The Migration of Constitutional Ideas (Cambridge: Cambridge University Press, 2007) 256, 261-62 (emphasizing that the presumption in favor of compliance with international law can be rebutted if international law violates jurisdictional, procedural or outcome-related principles).

17 Bogdandy, Dann \& Goldmann, n 6 above, 1389.

18 This classification is inspired by the account of Armin von Bogdandy, 'Globalization and Europe: How to Square Democracy, Globalization, and International Law’ (2004) 15 EJIL 885, 895-904.

19 See, e.g., Prosper Weil, 'Vers une normativité relative en droit international?’ (1982) 86 Revue générale de droit international public 5; Josef Isensee, 'Abschied der Demokratie vom Demos - Ausländerwahlrecht als Identitätsfrage für Volk, Demokratie und Verfassung' in Dieter Schwab, Dieter Giesen \& Joseph Listl (eds) Staat, Kirche, Wissenschaft in einer pluralistischen Gesellschaft. Festschrift für Paul Mikat zum 65. Geburtstag (Berlin: Duncker \& Humblot, 1989) 705; Curtis A. Bradley \& Jack L. Goldsmith, 'The Current Illegitimacy of International Human Rights Litigation' (1997) 66 Fordham L Rev 319; Paul B. Stephan, 'International Governance and American Democracy' (2000) 1 Chicago JIL 237; Roger P. Alford, 'Misusing International Sources to Interpret the Constitution' (2004) 98 AJIL 57. 
transformed into domestic law by the competent political institutions of the legislature or the executive. Through the formal act of transformation, the national institutions acquiesce to the decision of the international institution and legitimize their application by domestic courts.

\section{The internationalist paradigm and the focus on international procedures}

The opposite conception is the internationalist paradigm. ${ }^{20}$ The internationalists do not focus on the nation state. Rather, they examine the legitimacy of the international decisionmaking procedures on the basis of their proper architecture. In contrast to the sovereignty paradigm, the authority is not legitimate or illegitimate merely because of having been exercised by an international institution. In the domestic context, legitimacy concepts are often input-oriented and focus on whether citizens have at least indirectly participated in the political decision-making process. However, scholars adhering to the internationalist paradigm claim that it is impossible to apply domestic legitimacy standards to the international arena without modifications. ${ }^{21}$ Therefore, factors have to be identified that disassociate legitimacy from the nation state demos. ${ }^{22}$ Instead of focusing on participation, internationalists often try to identify factors that control the output of the political decision-making process. ${ }^{23}$ They do, therefore, not primarily focus on whether the affected citizens have - indirectly - participated in the political process, but whether the design of the decision-making procedures allows us to expect the decisions to meet certain qualitative standards. ${ }^{24}$

From an output-oriented perspective, political decisions bear two major risks: ${ }^{25}$ On the one hand, political actors or public officials may misuse their power and act in their private and not in the public interest; on the other hand, the substantive quality of the decisions may be insufficient because the officials are either incompetent or lack the necessary information. The danger that political agents may misuse their power occurs if the private and the public interest diverge, and the agents do not have incentives to act for the benefit of the common good. The principal mechanism to align the incentives with the public interest is holding political actors accountable. ${ }^{26}$ Within nation states, accountability is primarily

20 See Kingsbury, Krisch \& Stewart, n 5 above, 37-42; Terry Macdonald \& Kate Macdonald, ,NonElectoral Accountability in Global Politics: Strengthening Democratic Control within the Global Garment Industry' (2006) 17 EJIL 89; Erika de Wet, 'Holding International Institutions Accountable: The Complementary Role of Non-Judicial Oversight Mechanisms and Judicial Review' (2008) 9 German LJ 1987.

21 Allen Buchanan \& Robert O. Keohane, ,The Legitimacy of Global Governance Institutions' (2006) 20 Ethics \& International Affairs 405, 416-17.

22 Weiler, $\mathrm{n} 7$ above, at 560 .

23 On the distinction between input and output see David Easton, 'An Approach to the Analysis of Political Systems' (1957) 9 World Politics 383 (generally referring to political systems); Fritz W. Scharpf, Demokratietheorie zwischen Utopie und Anpassung (Konstanz: Universitätsverlag, 1970) 21 (on the specific issue of legitimacy).

24 For an attempt to justify for the shift from input- to output concerns in the international context, see Markus Jachtenfuchs, 'Theoretical Perspectives on European Governance' (1995) 1 ELJ 115, 128-29; Fritz W. Scharpf, Governing in Europe: Effective and Democratic? (Oxford: Oxford University Press, 1999) 10-21.

25 See $i d$., at 188.

26 Richard Mulgan, Holding Power to Account. Accountability in Modern Democracies (New York: Palgrave Macmillan, 2003) 10. 
achieved through elections and a hierarchical organization of the bureaucracy. ${ }^{27}$ Political actors who don't act in the public interest have to fear that they are not reelected, and the actions of public officials in the executive are controlled by their superiors.

As there are no elections in the inter- or supranational arena, this model cannot easily be transferred to international decision-making processes. ${ }^{28}$ However, there are alternative ways of shaping the incentives of political agents in the international context. Accountability has basically two requirements: first, it is necessary to obtain information about a potential misuse of power, and, second, there has to be a capacity to sanction the office holder if a misuse has occurred. ${ }^{29}$ Mechanisms ensuring the provision of information are the transparency of the decision-making process or the requirement to justify decisions by giving reasons. ${ }^{30}$

With regard to possible sanctions, losing the political office is a rigorous form of sanctioning the misuse of power, but there are other, less severe means that may ensure accountability. ${ }^{31}$ These include formal measures like disciplinary actions or informal ones, such as reputational sanctions. In the context of international organizations or international regulatory bodies, the formal measures may be exercised by supervisors or the member states. Reputational sanctions require a certain level of transparency and involve naming and shaming by the media or the general public. Accountability is thus a gradual concept that does not only allow either-or-judgments, but comes in different shades and degrees. Even if some mechanisms, such as elections, are not available on the international level, this does not mean that international actors cannot be held accountable to a certain degree.

The second element of output legitimacy, the quality of political decisions, can be understood in substantive as well as in procedural terms. With regard to substantive standards, it is difficult to formulate political standards for political decisions in advance. However, certain standards are derived from legal norms, ${ }^{32}$ which constitute the outer limits of political decisions. These norms include in particular the respect of the fundamental human rights and the principle of proportionality. ${ }^{33}$ Concerning the procedure, there is a controversial debate in political theory on whether it is possible to formulate any qualitative standards for political decisions that go beyond the requirement of accountability. ${ }^{34}$ However, this debate has so far barely resonated with the scholarship in international law and international relations.

27 See Jerry L. Mashaw, 'Structuring a "Dense Complexity": Accountability and the Project of Administrative Law’ (2005) 6 Issues in Legal Scholarship 1, 20.

28 Macdonald \& Macdonald, n 20 above, 92-99.

29 Ruth W. Grant \& Robert O. Keohane, 'Accountability and Abuses of Power in World Politics' (2005) 99 APSR 30.

30 On these criteria see Kingsbury, Krisch \& Stewart, n 5 above, 37-39.

31 Claus Offe, 'Political Corruption: Conceptual and Practical Issues' in János Kornai \& Susan RoseAckerman (eds) Building a Trustworthy State in Post-Socialist Transition (New York: Palgrave Macmillan, 2004) 77, 96.

32 Grant \& Keohane, n 29 above, 35.

33 Kingsbury, Krisch \& Stewart, n 5 above, 40-41.

34 One prominent attempt to introduce procedural safeguards for the quality of political decisions is the theory of deliberative democracy, see James S. Fishkin, Democracy and Deliberation: New Directions for Democratic Reform (New Haven: Yale University Press, 1991); Jürgen Habermas, Between Facts and Norms (Frankfurt aM: Suhrkamp, 1996) 287-328; John Ferejohn, 'Instituting Deliberative Democracy' in Ian Shapiro \& Stephen Macedo (eds) Designing Democratic Institutions (New York: New York University Press, 2000) 75. A second approach tries to account for the quality of decisions by partially delegating them to expert bodies, see 
What is discussed in the legal literature are more modest procedural safeguards, such as effective legal remedies in order to ensure compliance with the legal norms or an obligation to hear individuals affected by decisions of international bodies in order to ameliorate the informational basis on which these decisions are taken. ${ }^{35}$ These procedural safeguards can work in both directions: on the one hand, they can ensure the accountability of international decision-making processes, but on the other hand, they can also enhance the quality of the actual decisions.

Consequently, a court adhering to the internationalist paradigm examines the decisionmaking procedure of an international institution in order to decide whether it attributes direct effect to it. Executive and legislative decisions can typically be regarded as legitimate if their adoption process contains certain procedural safeguards that ensure the accountability of the decision-makers and a certain substantive quality of the decisions. In judicial decisions, accountability is difficult to achieve, as the independence of judges is often seen as a crucial element of adjudication. Therefore, domestic courts additionally apply a substantive standard, reviewing whether the jurisprudence of the international court does, in general, conform with the fundamental values of the domestic society, which are contained in the domestic constitution. A decision of an international court is attributed direct effect if its jurisprudence as a whole is considered as legitimate without every individual decision being substantively reviewed.

\section{The cooperation paradigm and the chain of legitimization}

In between these two positions, we find the cooperation paradigm. ${ }^{36}$ The cooperation paradigm shares with the sovereignty-centered approach that the nation states remain the central building blocks of the international legal order. The national citizenry is the ultimate source of legitimacy, and thus every political decision has, to a certain extent, to be attributable to the electorate of the nation state. ${ }^{37}$ The emergence of authority beyond the nation state is not excluded per se, but the evaluation of international authority is based on different criteria than under the internationalist paradigm. While the latter is concerned with the concrete design of international decision-making procedures and primarily

Giandomenico Majone, 'Independence vs. Accountability? Non-Majoritarian Institutions and Democratic Government in Europe' in Joachim Jens Hesse \& Theo A.J. Toonen (eds) The European Yearbook of Comparative Government and Public Administration (Baden-Baden: Nomos, 1994) 117; Christian Joerges, “'Good Governance” Through Comitology?” in Christian Joerges \& Ellen Vos (eds) EU Committees: Social Regulation, Law and Politics (Oxford: Hart, 1999) 311; Martin Shapiro, "Deliberative," "Independent" Technocracy vs. Democratic Politics: Will the Globe Echo the E.U.?' (2005) 68.3 Law \& Contemporary Problems 341. Finally, there are authors that argue that it is impossible to introduce qualitative decision-making standards beyond the mechanism of accountability, see Ian Shapiro, The State of Democratic Theory (Princeton: Princeton University Press, 2006) 39-43.

35 Kingsbury, Krisch \& Stewart, n 5 above, $37-38$ \& 40.

36 See Christian Walter, 'Constitutionalizing (Inter)national Governance' (2001) 44 German YIL 170; Rüdiger Wolfrum, 'Legitimacy in International Law from a Legal Perspective: Some Introductory Considerations' in Rüdiger Wolfrum \& Volker Röben (eds) Legitimacy in International Law (Berlin: Springer, 2008) 1; Stefan Kadelbach, 'Demokratische Legitimation als Prinzip zwischenstaatlichen Handelns' in Silja Vöneky, Cornelia Hagedorn, Miriam Clados \& Jelena von Achenbach (eds) Legitimation ethischer Entscheidungen im Recht - interdisziplinäre Untersuchen (Berlin: Springer, 2009) 147.

37 Ernst-Wolfgang Böckenförde, 'Demokratie als Verfassungsprinzip' in Josef Isensee \& Paul Kirchhof (eds) Handbuch des Staatsrechts. Band II: Verfassungsstaat, ch 24, para. 3 (Heidelberg: CF Müller, 3rd ed. 2004). 
evaluates them according to their expected output, the cooperation paradigm focuses on the share of (indirect) participation by the national citizens.

The exercise of authority is legitimate if it can be attributed to the citizenry by formal chains of attribution. ${ }^{38}$ International decisions can be attributed to the national demos in two ways: On the one hand, it is derived by an effective parliamentary control of the acts that delegate sovereign authority to supranational entities and the participation of legitimate representatives of the state in the international decision-making procedures. According to this understanding of legitimacy, supranational legislation, e.g. in the context of the European Union, is legitimate to the extent that either the national government or elected representatives of the nation state had a vote in the decision-making process. ${ }^{39}$

However, the concept of the formal chain of attribution only works for political decisions, but cannot be conferred to decisions of international courts and tribunals because judicial decisions usually do not derive their legitimacy from the indirect participation of citizens. National courts rather exercise a substantive review of each individual judgment of international courts, in which they assess whether the decision conforms to the fundamental values of the domestic society, which are expressed by the national constitution.

This approach differs both from the sovereignty and the internationalist paradigm. Under the sovereignty paradigm, a court would not accept the direct effect of a court judgment, unless it had been explicitly endorsed by the legislature. In contrast, a court adhering to the internationalist perspective would not make a substantive review of each individual judgment of an international court. Instead, it would take a broader approach and assess whether the jurisprudence conforms with the fundamental values of the domestic society in general.

\section{Three case studies on the perception of legitimacy by domestic courts}

In this section, we will try to evaluate three lines of constitutional jurisprudence according to the outlined theoretical classification. While the U.S. Supreme Court adheres to the sovereignty paradigm and insists on the positive implementation of international decisions by the national legislature, the approach of the European Court of Justice evaluates the design and the output of the international institutions themselves. The position of the German Bundesverfassungsgericht is in between these two perspectives. Although still performing a substantive examination of the exercise of international public authority, the Constitutional Court does not necessarily require such decisions to be implemented by the German legislature.

\footnotetext{
$38 \quad$ Id., para. 11.

39 Marcel Kaufmann, Europäische Integration und Demokratieprinzip (1997).
} 


\section{The state sovereignty paradigm - the U.S. Supreme Court and its judgments in Medellín and Sanchez-Llamas}

There are numerous decisions of the U.S. Supreme Court that deal with the effect of international treaties in U.S. domestic law. ${ }^{40}$ However, there are only very few instances, in which the court had to deal with the domestic effect of decisions of international institutions. All of these concern judgments of the International Court of Justice (ICJ). This section will focus on the two leading decisions in this respect. While, in Sanchez-Llamas v. Oregon, the Supreme Court had to deal with the authoritative effect of ICJ judgments when interpreting international legal norms, ${ }^{41}$ the decision in Medellin v. Texas ${ }^{42}$ was even more far-reaching. For the first time, the Court had to decide on the direct effect of an ICJ judgment to which the United States had been party and which was therefore legally binding for the U.S. In principle, the American Constitution establishes a monist concept with respect to international treaty norms in the domestic legal order. According to Art. VI para. 2,

"all treaties made, or which shall be made, under the authority of the United States, shall be the supreme law of the land; and the judges in every state shall be bound thereby, anything in the Constitution or laws of any State to the contrary notwithstanding."

However, the principle of direct effect has been narrowed early by the U.S. Supreme Court. In Foster \& Elam v. Neilson, the Court made a distinction between self-executing treaties having a direct effect in domestic law and non-self-executing treaties that are addressed to the political, not the judicial, institutions. ${ }^{43}$ The latter type has to be transformed into domestic law before they can be applied by the courts.

Subject of both decisions was a violation of Art. 36 of the Vienna Convention on Consular Relations. ${ }^{44}$ According to Art. 36 (1) lit. b of the Convention, arrested foreign nationals have to be informed that they have the right to notify the consular representation of their country of their arrest. In the course of this decade the United States had been convicted twice because of violations of this provision by the ICJ. ${ }^{45}$ In Sanchez-Llamas, one of the applicants relied on the interpretation of Art. 36 (1) of the Vienna Convention in the two ICJ judgments in order to make a claim regarding U.S. domestic law. In Medellin, the applicant was one of the individuals for whom Mexico had exercised diplomatic protection in the Avena case so that the ICJ judgment was directly legally binding for the U.S.

\section{The decision in Sancher-Llamas}

In Sanchez-Llamas, one of the applicants, Mario Bustillo from Honduras, had been convicted of first-degree murder. After the conviction had been confirmed on appeal and had become final, Bustillo filed a petition for writ of habeas corpus in a state court. There,

40 For an overview see Peter J. Spiro, 'Treaties, International Law, and Constitutional Rights' (2003) 55 Stanford LR 1999; Carlos Manuel Vázquez, 'Treaties as Law of the Land: The Supremacy Clause and the Judicial Enforcement of Treaties' (2008) 122 Harvard LR 599.

41 Sanchez-Llamas v. Oregon 548 US 331 (2006).

42 Medellin v. Texas 128 S. Ct. 1346 (2008).

43 Foster \& Elam v. Neilson 27 US 253, 314 (1829).

44 Vienna Convention on Consular Relations (24 April 1963), 596 UNTS 262.

45 LaGrand (Germany v. U.S.) [2001] ICJ Rep 466 (27 June); Avena and Other Mexican Nationals (Mexico v. U.S.) [2004] ICJ Rep 12 (31 March). 
for the first time, he argued that the American authorities had violated Art. 36 VCCR as they had not informed him about his right to contact the Honduran Consulate. With the help of the Consulate, it would have been much easier for him to prove his innocence during the criminal proceedings. The state habeas court dismissed Bustillo's claim as procedurally barred. He would have had to raise his claim based on the Vienna Convention before the conviction became final.

Applying to the U.S. Supreme Court, Bustillo argued that the application of this procedural default rule by the Virginia courts violated Art. 36 VCCR. In an earlier judgment, Breard $v$. Greene, the U.S. Supreme Court had already decided that a violation of Art. 36 VCCR did not bar the application of the procedural default rule. ${ }^{46}$ If the claim had not been raised in the state court proceedings, Art. 36 VCCR did not require states to modify their criminal procedure law. ${ }^{47}$ Bustillo argued that Breard was not applicable to his case because there had been two judgments of the International Court of Justice in the meantime, ${ }^{48}$ according to which the cure of a violation of the Vienna Convention must not be rendered impossible by procedural default rules.

The U.S. Supreme Court, however, rejected this argumentation. The interpretation of American domestic law is a task of American courts. Determining the domestic effect of an international treaty, is a matter of domestic law. ${ }^{49}$ Thus, the judgments of the ICJ have no directly binding force. They deserve, at best, "respectful consideration". ${ }^{50}$ However, the ICJ judgments do not take into account the importance of procedural default rules in an adversary system. While, in inquisitorial systems, mistakes are attributed to the judges, they fall into the responsibility of the parties in adversary systems. If Art. 36 VCCR was interpreted in a way that the application of the procedural default rule was excluded, this interpretation

"reads the ,full effect' proviso in a way that leaves little room for Article 36's clear instruction that Art. 36 rights ,shall be exercised in conformity with the laws and regulations of the receiving state." 51

Therefore, the interpretation of the ICJ could not be taken into account in the case of Mario Bustillo.

\section{The Medellin decision}

The judgment in Sanchez-Llamas paved the way for the Medellin decision, which was issued two years later. The applicant in Medellin had been sentenced to death because of murder and joint rape. After his conviction, he filed a babeas corpus petition and claimed that he had not been informed of his rights under Art. 36 (1) lit. b of the Vienna Convention. During the habeas proceedings, the ICJ issued the Avena decision, in which the Court found that the United States had violated the Vienna Convention on Consular Relations. Medellin had been one of the 51 Mexican nationals for whom Mexico had filed the procedure before the ICJ. In its decision the Court asked the United States

\footnotetext{
46 Breard v. Greene 523 US 371 (1998) (per curiam).

47 Id., at 375.

48 The judgments in the cases LaGrand and Avena, n 45 above.

49 Sanchez-Llamas, n 41 above, 353-54.

$50 \quad I d$., at 355 .

$51 \quad$ Id., at 357.
} 
"[to] provide, by means of its own choosing, review and reconsideration of the conviction and sentence, so as to allow full weight to be given to the violation of the rights set forth in the Convention." 52

As Medellín was among the beneficiaries of Mexico's application, the judgment was binding for his proceedings in terms of international law. After the rendition of the judgment, President George W. Bush issued an executive order in which he asked the American courts to give effect to the ICJ decision:

"I have determined, pursuant to the authority vested in me as President by the Constitution and the laws of the United States of America, that the United States will discharge its international obligations under the decision of the International Court of Justice in [Avena], by having State courts give effect to the decision in accordance with general principles of comity in cases filed by the 51 Mexican nationals addressed in that decision." 53

Despite the ICJ judgment and the memorandum of George Bush, the Fifth Circuit rejected the habeas application of Medellín. ${ }^{54}$ In his proceedings before the Supreme Court, the applicant hence claimed that the Fifth Circuit had violated the Supremacy Clause of the American Constitution. In its decision the Court had therefore to decide whether judgments of the International Court of Justice have direct domestic effect. The central international norm in this respect is Art. 94 (1) of the U.N. Charter ${ }^{55}$ according to which

"[e]ach member of the United Nations undertakes to comply with the decision of the International Court of Justice in any case to which it is party."

On the face, the Supreme Court based his decision on the text of the U.N. Charter. The terms "undertakes to comply" emphasizes, in the opinion of the Court, that a state only enters into an obligation to react on a judgment by political means. ${ }^{56}$ This interpretation is supposed to be supported by the context of the norm. Art. 94 (2) of the U.N. Charter provides a political and no legal remedy: If states do not comply with an ICJ judgment, they have to refer to the U.N. Security Council. ${ }^{57}$

In substance however, the judgment is motivated by considerations stemming from constitutional theory, or, more precisely, the doctrine of the division of powers. As the field of external relations is very sensitive, decisions on the implementation of international law should be left to the political, not the judicial, organs. ${ }^{58}$ The Court underlines that "it is not for the federal courts to impose one [particular remedy] on the States through lawmaking of their own. ${ }^{, 59}$ This judicial self-restraint can be interpreted in a twofold way. One might be inclined to read the reasoning of the court from an ex ante perspective according to which it is the function of the courts to abide by the law. The courts have to implement the intent of the political bodies, and this approach can best be implemented by a close adherence to the text of the norm created by the political institutions.

However, such an approach has several flaws. Linguistic expressions do not have only one single meaning. Their interpretation always depends on the interpreter and his cultural and

52 Avena, n 45 above, para 153.

53 Memorandum of President George W. Bush, 28 Feb. 2006, App. to Pet. for Cert. 187a.

54 Medellin v. Dretke 371 F.3d 270 (2004).

55 Charter of the United Nations (26 July 1945), TS 993.

56 Medellin, n 3 above, 128 S Ct 1346, 1358.

57 Id., at 1359.

58 Id., at 1364.

$59 \quad$ Id., at 1361 (emphasis added). 
social imprint. ${ }^{60}$ This is highlighted by Justice Breyer's dissenting opinion in Medellin that consults dictionary definitions and refers to the Spanish version of the U.N. Charter in order to show that the terms "undertakes to comply" employed by Art. 94 can also express an immediate legal obligation. ${ }^{61}$ Furthermore, it is particularly unrealistic in the realm of international treaties to expect the text to say anything about the domestic effect of the treaty. ${ }^{62}$ The implementation of international norms differs from state to state. The differentiation between self-executing and non-self-executing is only significant from the view-point of the domestic legal order, but not from the angle of international law, as the latter demands unconditional compliance anyway. ${ }^{63}$

Medellin has thus to be read as a proposition of an expost control model. According to this model, decisions of international institutions with domestic effect are subject to political control. The Supreme Court emphasizes that it is not the task of the judiciary to exercise such control. ${ }^{64}$ Furthermore, the Court holds that the president did not have the power to order an implementation of the judgment by means of an executive memorandum. ${ }^{65}$ The implementation of the decision of an international tribunal thus requires a positive act of the U.S. Congress or state legislature, which have full political control over how to implement the decision in question. ${ }^{66}$ Consequently, international decisions cannot have any direct effect in the US legal order unless they have been positively embraced by the legislature so that all political decisions have finally to be made within the arena of the nation state. The U.S. Supreme Court therefore implicitly adheres to the state sovereignty paradigm.

\section{The internationalist paradigm - the jurisprudence of the European Court of Justice}

The opposite approach is represented by the jurisprudence of the European Court of Justice. To be sure, the European Union is not a state and the ECJ thus not a constitutional court in the statist sense of the notion. However, the problem of attributing direct effect to law that originated in a distinct legal order, is not exclusively a problem of domestic law. In recent decades, some supranational legal orders have developed, in which the process of law creation differs considerably from the traditional sources doctrine of international law. The most notable example in this respect is the European Union, whose legal order has developed into a constitutional order, showcasing all relevant characteristics of such a

60 See Hans-Georg Gadamer, Wabrheit und Methode. Grund₹üge einer philosophischen Hermeneutike (Tübingen: Mohr, 6th ed. 1990) 270.

61 Medellin, n 3 above, 128 S Ct 1346, 1384 (Breyer J. dissenting).

62 Id., at 1363-64.

63 Vázquez, n 40 above, 634; Karen Kaiser, 'Treaties, Direct Applicability' in Rüdiger Wolfrum (ed) Max Planck Encyclopedia of Public International Law (Oxford: Oxford University Press, 2008) para. 6.

64 Medellin, n 3 above, 128 S Ct 1346, 1364 ("it is hardly that the judiciary should decide which judgments are politically sensitive and which are not").

65 Id., at 1368-72. But see Carlos Manuel Vázquez, 'Less Than Zero?' (2008) 102 AJIL 563 (criticizing the reasoning of the Supreme Court).

66 The consistency of this reasoning has been criticized by some scholars as it limits the ex ante autonomy to enter into treaties in the name of the expost autonomy to be independent of treaties. See Steve Charnovitz, 'Revitalizing the U.S. Compliance Power' (2008) 102 AJIL 551, 557 (“The Court seems to have overlooked the compelling U.S. interest of assuring uniformity in U.S. foreign policy”). 
system. ${ }^{67}$ Its law-making process is closer to legislation within nation-states than to the diplomatic, consensus-oriented bargaining in the international arena so that the coordination with the international legal order poses similar problems as in domestic law. ${ }^{68}$

In several instances, the ECJ had to decide on the status of international law in the EU legal order. In its decisions the ECJ primarily adopts an internationalist standpoint. In the following, this shall be highlighted by focusing on three different strands of the ECJ jurisprudence. First, there is a considerable amount of judgments dealing with the importance of decisions of the European Court of Human Rights for the interpretation of human rights within the EU legal system. Second, the ECJ has, over a series of decisions, developed a standpoint on the direct effect of decisions of the WTO dispute settlement system within the EU order. Finally, the recent Kadi decision ${ }^{69}$ of the ECJ had to answer the question, whether it is possible to review acts transforming resolutions of the UN Security Council with regard to principles forming part of the European constitutional order.

\section{Interpretation of buman rights and the Strasbourg jurisprudence}

The relationship of the ECJ to human rights has not always been an easy one. In first years of the European integration, the ECJ did not refer to human rights at all. There seemed to be no need in this respect, as the founding treaties of the European Communities did not contain an explicit human rights catalogue. However, the Court quickly realized that it had to take into account the individual rights dimension of the cases brought before it, if it wanted to ensure the acceptance of its jurisprudence by the courts of the Member States. ${ }^{70}$ It thus started to develop a human rights jurisprudence, which has been acknowledged by Art. 6 (3) of the EU Treaty ${ }^{71}$, which requires the EU institutions to respect fundamental rights as guaranteed by the ECHR and as they result from the common traditions of the Member States. However, as the European Union did, until very recently, not have a legally binding human rights catalogue, ${ }^{72}$ the ECJ always had to 'import' human rights from other legal systems. In practice, the ECJ principally refers to the provisions of the European

67 Case 294/83 Les Verts v. European Parliament [1986] ECR 1357, para. 23, and Opinion 1/91, EEA [1991] ECR I-6099, para. 21. For a detailed discussion of this issue see Niels Petersen, 'Europäische Verfassung und europäische Legitimität - ein Beitrag zum kontraktualistischen Argument in der Verfassungstheorie' (2004) 64 Heidelberg JIL 429.

68 Certainly, the strategic position of the ECJ differs, to a certain extent, from the one of domestic courts because the ECJ not only has to take international institutions into account, but also the courts of the member states. This makes it, e.g., less likely that the ECJ embraces the sovereignty paradigm. In theory, however, a sovereignist position would be possible. One might argue that the ECJ could not adopt such a position because it lacks a proper demos. However, the demos is not something organic, but, basically, a social construction. It is therefore not important that there actually is something like a European demos, but whether the ECJ constructs a European demos (e.g. on the basis of the European citizenship) as the basis of its legitimacy conception.

69) See $\mathrm{n} 4$ above.

70 Cf. Case BvL 52/71, Solange I [1974] 37 Entscheidungen des Bundesverfassungsgerichts 271 (Federal Constitutional Court, 29 May 1974); Frontini v. Ministero delle Finanze [1974] 14 CMLR 372 (Corte costituzionale, 27 December 1973).

71 Treaty on European Union, consolidated version: OJ C 83/13 (30 March 2010) [hereinafter: TEU].

72 Through the Treaty of Lisbon, the Charter of Fundamental Rights has become part of EU primary law, Art. 6 (1) TEU. 
Convention on Human Rights ${ }^{73}$ as expressions of the common traditions of the EU Member States.

The institution mandated with the coherent interpretation of the Convention is the European Court of Human Rights, though, not the ECJ. Therefore, there has been much debate on whether the ECJ has to take the jurisprudence of the ECtHR into account when applying the rights of the Convention in the context of the EU. ${ }^{74}$ Although the European Union is not formally bound by the Convention, there would be potential for serious conflict if the ECJ interpreted its guarantees in a different way than the ECtHR.

The ECJ has never expressly clarified its relationship to the ECtHR and whether it feels bound by the latter's jurisprudence. ${ }^{75}$ However, it has implicitly recognized the Strasbourg jurisprudence as authoritative. When interpreting provisions of the ECHR, the Luxemburg Court frequently refers to and cites judgments of the ECtHR. ${ }^{76}$ In Schmidberger, e.g., the ECJ cites the ECtHR for the statement that the freedom of expression and the freedom of assembly are no absolute guarantees under the ECHR, but that they may be subject to restrictions. ${ }^{77}$ In RTL Television, the Court referred to the margin of appreciation doctrine of the ECtHR in order to justify a restriction of Art. 10 ECHR. ${ }^{78}$

There are no examples in which the ECJ openly opposed a decision from Strasbourg. ${ }^{79}$ Even if Luxemburg did not follow Strasbourg, it was rather because it had probably overlooked that there is Strasbourg case law in this respect than because of disagreement. ${ }^{80}$

73 Convention for the Protection of Human Rights and Fundamental Freedoms (4 November 1950), 213 UNTS 222.

74 See, e.g., Marco Bronckers, 'The Relationship of the EC Courts with other International Tribunals: Non-Committal, Respectful or Submissive?' (2007) 44 CMLR 601; Guy Harpaz, 'The European Court of Justice and Its Relations with the European Court of Human Rights: The Quest for Enhanced Reliance, Coherence and Legitimacy' (2009) 46 CMLR 105, 115-41.

75 Id., at $109-10$.

76 Sionaidh Douglas-Scott, 'A Tale of Two Courts: Luxembourg, Strasbourg, and the Growing European Rights Acquis' (2006) 43 CMLR 629, 644-52; Philip Alston \& Joseph H.H. Weiler, 'An 'Ever Closer Union' in Need of a Human Rights Policy' (1998) 9 EJIL 658, 686; Matthias Ruffert, 'Die künftige Rolle des EuGH im europäischen Grundrechtsschutzsystem' (2004) 31 Europäische Grundrechte Zeitschrift 466, 471. For an, albeit not comprehensive, overview of cases, in which the ECJ has cited the ECtHR see Douglas-Scott, $i d$., at 644-45 (n 68).

77 Case C-112/00 Schmidberger v. Austria [2003] ECR I-5659, para. 79.

78 Case C-245/01 RTL Television GmbH [2003] ECR I-12489, para. 73.

79 There are certain instances of potentially conflicting jurisprudence, though. This concerns, in particular, the issue of the right to non-self-incrimination. See, on the one hand, Case 374/87 Orkem v. Commission [1989] ECR 3289 and, on the other hand, Funke v. France Series A No. 256-A [1993] 16 EHRR 297. However, the two cases do not refer to exactly the same situation, as the latter case also involved criminal proceedings. Therefore, it is doubtful that there is an actual conflict: see Vasilios Skouris, 'Introducing a binding Bill of Rights for the European Union' in Alexander Blankenagel, Ingolf Pernice \& Helmuth Schulze-Fielitz (eds) Verfassung im Diskurs der Welt (Tübingen: Mohr Siebeck, 2004) 261, 270-71. Some people also see a conflict in the question whether parties should have a right to respond to the opinion of the Advocate General, which was declined by the ECJ, see Case C-17/98 Emesa Sugar [2000] ECR I-667. The ECtHR later saw a violation of Art. 6 (1) ECHR in not giving a right to response in French administrative proceedings, after which the ECJ system is modeled: see Kress v. France [2001] EHRR 2001-VI. However, the main reason why the Court found the violation was that the French government commissioner participated in the deliberations of the Conseil d'Etat, which is not the case for the European Advocate General.

80 See Dean Spielmann, 'Human Rights Case Law in the Strasbourg and Luxembourg Courts: Conflicts, Inconsistencies, and Complementarities' in Philip Alston (ed) The EU and Human Rights (Oxford: Oxford University Press, 1999) 757, 770 (referring to two cases, in which the ECJ did not respect the precedents of 
The ECJ has even changed its own jurisprudence in several occasions if the ECtHR took a different position on issues that had already been decided by the ECJ. ${ }^{81}$ In Hoechst, e.g., the ECJ found that there was no case law of the ECtHR on the inviolability of business premises and held that the right to privacy established by Art. 8 ECHR did not apply to businesses. ${ }^{82}$ When the ECtHR extended the protection of Art. 8 ECHR to businesses in a later judgment, ${ }^{83}$ the ECJ changed its jurisprudence in Roquette Frères and acknowledged that business premises could also be protected under Art. 8 ECHR. ${ }^{84}$

This strategy of the ECJ vis-à-vis the jurisprudence of the ECtHR fits into the patterns of the internationalist paradigm. By frequently citing the ECtHR and adopting its standards, the ECJ basically accepts Strasbourg's human rights jurisprudence. As the ECJ does not explicitly discuss the status of the ECtHR jurisprudence in EU law, it is possible to come up with different explanations for this observation. One might be inclined to argue that the reasons are of purely strategic nature assuming that Luxemburg wants to avoid any conflict with Strasbourg. However, the ECJ does not shy away from conflicts with other judicial organs, such as the WTO Appellate Body, ${ }^{85}$ so that there has to be at least an additional explanation for the conduct of the ECJ. One way of interpreting this conduct is that the Court implicitly regards the judgments of the ECtHR as legitimate. The standard of assessment would be a substantive one - human rights, or, more precisely, the particular human rights understanding of the ECJ. This would also explain why the ECJ has not yet taken a clear stance on this issue and expressly accepted the unconditional supremacy of the ECtHR. As there is no guarantee that the substance of the ECtHR jurisprudence may not vary, it formally reserves itself the right to deviate if circumstances should change and major disagreements arise.

\section{WTO dispute settlement and the lacking constitutional order}

The direct effect of World Trade law in the EU legal order has been subject to much debate in legal scholarship. Many authors have seen parallels to the integration process within the European Communities and thus claimed that the ECJ should give direct effect to World Trade law in the same way as it requires the EU member states to give direct effect to legal norms of the EU order. ${ }^{86}$ The ECJ has, however, been reluctant in this respect. Even before the establishment of the WTO, it held that provisions of the General

the ECtHR, but "took for granted that there is no case-law of the European Court of Human Rights on the subject").

81 Douglas-Scott, n 76 above, 649; Robin C.A. White, 'The Strasbourg Perspective and its Effect on the Court of Justice: Is Mutual Respect Enough?' in Anthony Arnull, Piet Eeckhout \& 'Takis Tridimas (eds) Continuity and Change in EU Law. Essays in Honour of Sir Francis Jacobs (Oxford: Oxford University Press, 2008) 139, 142 .

82 Joined Cases 46/87 and 227/88, Hoechst AGv. Commission [1989] ECR 2859.

83 Niemitz v. Germany Series A No. 251-B [1992] 16 EHRR 97.

84 Case C-94/00, Roquette Frères SA v. Commission [2002] ECR I-9011, para. 29.

85 On this issue, see below 000.

86 See Ernst-Ulrich Petersmann, 'Application of GATT by the Court of Justice of the European Communities' (1983) 20 CMLR 397; Stefan Griller, 'Judicial Enforceability of WTO Law in the European Union' (2000) 3 JIEL 441, 450-54. See also Piet Eeckhout, 'The Domestic Legal Status of the WTO Agreement: Interconnecting Legal Systems' (1997) 34 CMLR 11, 53 (emphasizing that WTO obligations should have a direct effect in the community legal order of the violation of WTO law is established by the DSB). 
Agreement on Tariffs and Trade ${ }^{87}$ do not have direct effect in the community legal order. ${ }^{88}$ It affirmed this line of jurisprudence also for the context of the WTO ${ }^{89}$ and extended this rationale to decisions of the WTO dispute settlement system.

In Biret International, ${ }^{90}$ the ECJ had to decide whether a French company could claim compensation for damages from the Community for violating the SPS Agreement ${ }^{91}$. In 1988 and 1996, the Council adopted directives 88/146/EEC ${ }^{92}$ and 96/22/EC ${ }^{93}$ prohibiting the importation of meat of animals treated with certain hormones. In January 1998, the Appellate body of the WTO found that these directives were in breach of the SPS Agreement. ${ }^{94}$ The plaintiff, Biret International, thus claimed that the European Community was liable under the EC treaty because it had violated WTO law. However, the ECJ left open, whether the Appellate body decision has a direct effect in the Community legal order. As the Community had a certain time frame in which to implement the Appellate body decision, the ECJ held that a claim for damages could not arise before the expiration of this period..$^{5}$ Damages for the time after the expiration of the implementation period had not been asserted by the plaintiff. ${ }^{96}$

In the Van Parys judgment, the ECJ went one step further and held that decisions of the WTO dispute settlement system did not have a direct effect in the EU legal order. ${ }^{97}$ The case refers to the banana import system established by the EC, which differentiates between bananas imported from ACP States and those imported from non-ACP third states. In 1997, the WTO Appellate Body found that this system was incompatible with certain provisions of the GATT. ${ }^{98}$ In 1998 and 1999, the plaintiff applied for import licences for bananas from Ecuador. The Belgian authorities, due to respective EC regulations, only granted a certain quota of the applied quantities. Van Parys took legal actions against these decisions, and claimed that they should not be based on the EC regulations, as the latter were incompatible with WTO law.

In its decision, the ECJ refers to its established jurisprudence that World Trade law has no direct effect in the EU legal order, and that DSB decisions could therefore not have such an effect either. ${ }^{99}$ The Court principally puts forward two arguments: first, it underlines that the WTO dispute settlement system is not a fully developed judicial system, but that it accords considerable importance to negotiation between the parties - even after a DSB

87 General Agreement on Tariffs and Trade, 55 UNTS 194 (30 Oct. 1947).

88 Case 21-24/73, International Fruit Company [1972] ECR 1219.

89 Case C-149/96, Portugal v. Council [1999] ECR I-8395.

90 Case C-94/02 P, Biret International v. Commission [2003] ECR I-10497.

91 WTO Agreement on the Application of Sanitary and Phytosanitary Measures (15 April 1994), 1867 UNTS 493.

92 O.J. 1988 L 70, p. 16.

93 O.J. 1996 L 125, p. 3.

94 European Communities - Measures Concerning Meat and Meat Products, WT/DS26/AB/R, WT/DS48/AB/R (Appellate Body Report, 16 January 1998).

95 Biret, n 90 above, para. 65.

96 Id., para. 67.

97 Case C-377/02, V an Parys [2005] ECR I-1465.

98 European Communities - Regime for the Importation, Sale and Distribution of Bananas, WT/DS27/AB/R (Appellate Body Report, 9 September 1997).

99 Van Parys, n 97, para. 41. 
decision has been issued. ${ }^{100}$ If DSB decisions had direct effect, this would deprive the political organs of the EU of their room for negotiation afforded by the procedural provisions of the DSB. ${ }^{101}$ Second, the WTO system is built upon the principle of reciprocity. There are some member states of the WTO which deny World Trade law direct effect within their domestic legal order so that it would again deprive the political organs of the EU of considerable room for manoeuvre. ${ }^{102}$

In IKE $A$, the plaintiff relied on a decision of the WTO Appellate Body ${ }^{103}$ in order to claim that regulation 2398/97 ${ }^{104}$ was invalid because it violated the Anti-Dumping Agreement ${ }^{105}$ of the WTO. ${ }^{106}$ IKEA thus requested the competent British customs authority to reimburse the anti-dumping duties that it had paid under the contested regulation. The ECJ, however, rejected the request. It argued that WTO dispute settlement decisions had only prospective and no retroactive effect. Furthermore, the Community had made it clear by the regulations subsequent to regulation 2398/97 that it intended to exclude repayments. Because of a political will to the contrary, the ECJ could thus not grant repayments to IKEA despite the illegality of regulation 2398/97 under World Trade law.

In the FLAMM judgment, the plaintiffs claimed damages for losses incurred under trade sanctions. ${ }^{107}$ These sanctions had been imposed by the United States because of noncompliance of the European Union with the Appellate Body decision in the banana litigation. In its decision, the ECJ repeated its argument that the direct effect of Appellate Body decisions would deprive the Community's executive and legislative organs of the necessary scope for manoeuvre. ${ }^{108}$ This is even the case if the time for implementing the decision has expired. ${ }^{109}$ The Court further argues that there cannot be different considerations if the action is for compensation instead of annulment. ${ }^{110}$ Therefore, it dismissed the claim of the plaintiffs.

Considered in isolation, the ECJ jurisprudence vis-à-vis the effect of WTO in the community legal order resembles the discussed judgments of the U.S. Supreme Court. As the latter, the ECJ relies on the will of the political institutions and thus denies any direct effect of decisions of the WTO dispute settlement system. However, there are significant differences. While the U.S. Supreme Court is reluctant to accept the direct effect of decisions of international institutions in general, the ECJ always stresses the particularity of

\footnotetext{
100 Id., para. 42.

101 Id., para. 48.

102 Id., para. 53.

103 European Communities - Anti-Dumping Duties on Imports of Cotton-Type Bed Linen from India, WT/DS141/AB/R (Appellate Body Report, 1 March 2001).

104 Council Regulation (EC) 2398/97 (28 November 1997).

105 Agreement on Implementation of Article VI of the General Agreement on Tariffs and Trade 1994 (Anti-Dumping) (15 April 1994), 1868 UNTS 201.

106 Case C-351/04, IKEA Wholesale Ltd. [2007] ECR I-7723.

107 Joined Cases C-120/06 P and C-121/06 P, FLAMM and Fedon [2008] ECR I-6513.

108 Id., para. 119.

109 Id., para. 127.

110 Id., para. 124.
} 
the WTO dispute settlement. ${ }^{111}$ These concern especially the political nature of the world trade system and the resulting importance of the principle of reciprocity.

The Court thus seems to fear that the European Union would be at a disadvantage compared to the United States if decisions of the WTO Appellate Body had direct effect in EU law. This would make trade law more effective within the European legal order and thus deprive the Commission of a bargaining chip in its negotiations with the US and other members of the WTO. Unlike the US Supreme Court in Medellin, which explicitly mentions legitimacy concerns, the jurisprudence of ECJ is clearly driven by strategic considerations. Even if there might be legitimacy concerns, ${ }^{112}$ these are not explicitly mentioned by the ECJ. The WTO jurisprudence of the ECJ is thus an illustration that legitimacy is not the only concern of courts dealing with decisions of international institutions. In some cases, legitimacy considerations may rather be overridden by strategic concerns.

\section{The U.N. Security Council and the Kadi decision}

In a recent decision, Kadi v. Council and Commission, the ECJ had to decide about the effect of resolutions of the UN Security Council in the EU legal order. The constellation in Kadi is slightly different than the ones discussed before. While the ECJ usually has to decide whether decisions of an international authority have an immediate effect in domestic law without any further implementation by the legislature, the ECJ had to decide whether a positive act of the European legislature was immune against constitutional review because it had been determined by a decision of an international institution. The European Union had issued a Council regulation in order to implement a resolution of the U.N. Security Council within the European Union. However, in order to decide whether EU law that is predetermined by international obligations can be subject to judicial review, the ECJ still had to determine the effect of international law within the Community legal order. Namely, it had to judge whether the Security Council decision was superior to EU primary law.

The starting point of the case was a resolution of the U.N. Security Council directed against terrorism and specifically against Al-Qaida. After the attack on the U.S. embassies in Nairobi and Dar es Salaam in 1998, the Security Council issued Resolution 1267 requesting all states to freeze all funds and other financial resources directly belonging or otherwise related to the Taliban. ${ }^{113}$ The resolution also established a Sanctions Committee in order to manage these sanctions. One year later, Resolution 1333 authorized the Sanctions Committee to maintain an updated list of individuals and organizations designated as associated with the Taliban. ${ }^{114}$ In order to implement these resolutions into

111 See Robert Uerpmann-Wittzack, 'The Constitutional Role of Multilateral Treaty Systems' in European Constitutional Law, n 9 above, 145, 158 (emphasizing that the ECJ uses procedural arguments for rejecting direct applicability of WTO law).

112 Such concerns are voiced, e.g., by Robert Howse \& Kalypso Nicolaïdis, 'Legitimacy and Global Governance: Why Constitutionalizing the WTO Is a Step Too Far', in Roger B. Porter et al. (eds) Efficiency, Equity, and Legitimacy. The Multilateral Trading System at the Millennium (Washingon DC: Brookings Institution Press, 2001) 227, 245; Armin von Bogdandy, 'Legal Equality, Legal Certainty and Subsidiarity in Transnational Economic Law - Decentralized Application of Art. 81.3 EC and WTO Law: Why and Why Not' in Armin von Bogdandy, Petros C. Mavroidis \& Yves Mény (eds) European Integration and International Coordination. Studies in Transnational Economic Law in Honour of Claus-Dieter Eblermann (The Hague: Kluwer, 2002) $13,29$.

\footnotetext{
113 U.N. Doc. S/RES/1267 (15 October 1999).
}

114 U.N. Doc. S/RES/1333 (19 December 2000). 
EU law, the Council issued Regulation 881/2002, which ordered the freezing of the funds of all persons contained on the list of the U.N. Sanctions Committee. ${ }^{115}$ The listed individuals did not have an opportunity for an independent review of their status.

The applicants, who were contained in the mentioned list, brought an action of annulment of the EC regulation to the European Court of First Instance (CFI). They argued, in particular, that the regulation violated their fundamental rights. The CFI, however, dismissed the actions. ${ }^{116}$ It held that United Nations law had supremacy over EU law and that Security Council resolutions could thus not be reviewed under European constitutional law. The only legal standard for the control of Security Council resolutions was international ius cogens. The Court found, however, that the measures enacted by the Security Council resolution did not violate ius cogens.

In the appeal procedure, the ECJ rejects this argumentation. It holds that even those legislative acts of the European Union that are predetermined by international law have to be subject to review under the constitutional principles of the EU. The Court establishes that the values enshrined in Art. 6 (1) of the pre-Lisbon version of the Treaty on European Union $^{117}$ - liberty, democracy and the respect for human rights and fundamental freedoms - are the foundation of the European Union, from which no derogation is possible. ${ }^{118}$ United Nations law can thus only have primacy over secondary Community law, but that primacy cannot extend to the constitutional provisions, in particular the fundamental rights guaranteed by the Union. ${ }^{119}$

The ECJ continues to examine whether the listing procedure of the U.N. Sanctions Committee had violated fundamental rights, in particular the right to defense, the right to an effective judicial review and the right to property. The rights to defense and judicial review contain, in particular, a right to be informed about the reasons for the imposition of the measure in question. ${ }^{120}$ As the applicants had not been informed about the reasons for their inclusion in the list of the U.N. Sanctions Committee, these guarantees were violated. ${ }^{121}$ With regard to the right to property, the Court holds that the freezing of funds and other economic resources could not be regarded as inappropriate per se in order to fight against persons connected to terrorism. ${ }^{122}$ However, the confiscation of property has to include certain procedural guarantees. As the contested regulation did not furnish any guarantee enabling the applicants to put their case to the competent authorities, the ECJ considered the right to property to be violated. ${ }^{123}$

In the Kadi decision, the ECJ does not review an individual decision to impose a sanction against a specific individual, but the whole sanctioning system established by the Security Council as such. In evaluating this system, the Court adopts an internationalist

115 Council Regulation (EC) 881/2002 (27 May 2002).

116 Case T-315/01, Yassin Abdullah Kadi v. Council and Commission, [2005] ECR II-3649 and Case T-306/01, Ahmed Ali Yusuf and Al Barakaat International Foundation v. Council and Commission, [2005] ECR II-3533.

117 Treaty on European Union, consolidated version: OJ C 321E (29 Dec. 2006).

118 Kadi, n 4 above, para. 303.

119 Id., paras. 307-8.

120 Id., para. 336.

121 Id., para. 353.

122 Id., para. 363.

123 Id., paras. 368-69. 
perspective. ${ }^{124}$ Unlike the sovereignty and the cooperation paradigm, which derive the legitimacy of international decision-making to a certain extent from the participation of domestic authorities, internationalists focus on the procedural guarantees of the international decision-making process. ${ }^{125}$ And here the ECJ finds certain fundamental flaws. The EC regulation was annulled because the procedure before the sanctions committee did not respect certain procedural rights that are supposed to enhance the accountability and the quality of the committee's decisions. The persons who were listed by the UN Sanctions Committee were neither heard before the decision was taken nor given reasons for their treatment nor did they have an effective legal remedy. ${ }^{126}$ Certainly the standards of evaluation are neither some abstract legitimacy considerations nor originating in international documents, but EU fundamental rights. ${ }^{127}$ However, as courts are judicial bodies, they have to express legitimacy considerations in legal terms in order not to undermine their own legitimacy. ${ }^{128}$ At the same time, the procedural rights examined by the ECJ are not specific to the EU context, but are often also discussed in the framework of general legitimacy concepts. ${ }^{129}$

Finally, the Court does not exclude to reduce the extent of its own judicial review if an appropriate review mechanism were installed on the international level. In the proceedings, the Commission had argued that the ECJ must not exercise judicial review as long as the individuals concerned have an acceptable opportunity of independent review forming part of the United Nations system. The Court does not reject this argument in principle, but only on factual grounds, as adequate judicial protection is not guaranteed. ${ }^{130}$ Immunity is not unjustified per se. Instead, the ECJ deemed it unjustified "for clearly that re-examination procedure does not offer the guarantees of judicial protection." 131 The Court thus indicates

124 But see Takis Tridimas, 'Terrorism and the ECJ: Empowerment and democracy in the EC legal order' (2009) 34 ELR 103, 111, who qualifies the approach of the ECJ as "firmly a sovereignist one." The difference in the evaluation is probably due to the different use of the term "sovereignist", as Tridimas asserts that the ECJ had to take this step for legitimacy reasons (id., at 126). Furthermore, the evaluation of this contribution runs counter to some commentaries that lauded the decision of the Court of First Instance for its respect of international law and would thus be critical of the ECJ judgment. See, e.g., Andreas von Arnauld, 'UNSanktionen und gemeinschaftsrechtlicher Grundrechtsschutz' (2006) 44 Archiv des Völkerrechts 201; Christian Tomuschat, 'Case Comment' (2006) 43 CMLR 537. However, the standards of evaluation are different, as this contribution does not focus on legality, but rather on legitimacy. For a critique of the constitutionalist starting point of these case comments see Jean d'Aspremont \& Frédéric Dopagne, 'Two Constitutionalisms in Europe: Pursuing an Articulation of the European and International Legal Orders' (2009) 69 Heidelberg JIL 939.

125 See above, pp 5-7.

126 Kadi, n 4 above, paras. 348-53. See also Kumm, n 16 above, at 289, who claims that the resolutions should not be implemented in the EU legal order because they violate the principle of procedural accuracy.

127 This has been critiqued by several authors, see Luis M. Hinojosa Martínez, 'Bad Law for Good Reasons: The Contradictions of the Kadi Judgment' (2008) 5 IOLR 339, 344; Gráinne de Búrca, The European Court of Justice and the International Legal Order after Kadi, Jean Monnet Working Paper 01/09, 47; Paul James Cardwell, Duncan French and Nigel White, 'European Court of Justice, Yassin Abdullah Kadi and Al Barakaat International Foundation v. Council and Commission (Joined Cases C-402/05 P and C-415/05 P) Judgment of 3 September 2008' (2009) 58 ICQL 229, 237.

128 See Alec Stone Sweet, Governing with Judges (2000) 200; Martin Shapiro \& Alec Stone Sweet, On Law, Politics, and Judicialization (2002) 165.

129 See above, n 35. In favor of the approach of the ECJ, therefore, Nikolaos Lavranos, 'The Impact of the Kadi Judgment on the International Obligations of the EC Member States and the EC' (2009) 28 YEL 616,624 .

\footnotetext{
130 Kadi, n 4 above, paras. 319-22.

131 Id., para. 322.
} 
that it would not interfere with the substantial considerations of concrete decisions of the UN Sanctions Committee if a legitimate procedure were put in place. ${ }^{132}$ This shows that the court does not want to retain the complete substantive control of the decisions of the Committee, as would be characteristic for the cooperation paradigm. Instead, it only wants to ensure the general legitimacy of the decision-making procedure.

\section{Evaluation}

The case law of the ECJ on the effect of decisions of international authority within the EU legal system is not entirely homogenous. While the Court basically accepts the jurisprudence of the ECtHR when interpreting the guarantees of the European Convention of Human Rights, it does not concede direct effect to decisions of the WTO dispute settlement body as well as to resolutions of the UN Security Council. Contrary to the jurisprudence of the U.S. Supreme Court, this is, however, not a rejection of a direct effect of international 'secondary' law per se. The Court attributes the reason for not granting direct effect to the character of the specific régime. In Kadi, the Court is clearly driven by legitimacy concerns when it makes the resolution of the Security Council subject to judicial review under EU primary law. The WTO decisions are, in principle, motivated by political considerations. Here, legitimacy considerations are pushed aside because of strategic concerns, as the ECJ fears that the European institutions might have a disadvantage vis-à-vis other WTO members if decisions of the Appellate Body were granted direct effect.

With the exception of the WTO jurisprudence, the Court thus adopts an internationalist perspective. It neither accepts unconditional direct effect of international decisions, nor does it reject direct effect per se. The legitimacy standards applied by the court take into account the concrete design of the respective institution and focus on its output. In its human rights jurisprudence, the court follows the decisions of the ECtHR because the history of the jurisprudence suggests that the judgments are, in principle, acceptable in their substance; in Kadi, the court intervened because the listing procedure did not respect certain procedural guarantees necessary to ensure legitimate decisions.

\section{The cooperation paradigm - the jurisprudence of the German Bundesverfassungsgericht}

The jurisprudence of the German Bundesverfassungsgericht can be situated somewhere in between the two strategies highlighted so far. When analyzing the decisions of the Federal Constitutional Court, two strands have to be distinguished. On the one hand, there is the jurisprudence on the relationship to the European Union and the European Court of Justice, which is characterized by the special nature and the high degree of integration of the EU legal order. In this respect, the Constitutional Court basically accepts the supremacy of secondary community law and generally recognizes that the European Court of Justice has the exclusive right to review the legality of all acts of EU institutions. On the

132 Accord E. Cannizzaro, 'Security Council Resolutions and EC Fundamental Rights: Some Remarks on the ECJ Decision in the Kadi Case' (2009) 28 YEL 593, 596-97 (qualifying the passage as "Solange argument, forged in ECJ style"); Mehrdad Payandeh \& Heiko Sauer, "European Union: UN sanctions and EU fundamental rights' (2009) 7 I.CON 306, 314. But see also the contrary evaluation of the same passage of Daniel Halberstam and Eric Stein, 'The United Nations, the European Union, and the King of Sweden: Economic Sanctions and Individual Rights in a Plural World Order' (2009) 46 CMLR 13, 60. 
other hand, there is a different strand of judgments concerning the direct effect of decisions of other international courts and tribunals. Two recent judgments concerning decisions of the European Court of Human Rights and the International Court of Justice show that the Bundesverfassungsgericht is much more reluctant in this respect.

\section{The jurisprudence in the context of the European Union}

The relationship between the European Court of Justice and the German Federal Constitutional Court has not been free of tension. While the ECJ has always claimed that all community law should have direct effect in national legal orders, ${ }^{133}$ the Federal Constitutional Court has never accepted the unconditional supremacy of EU law. However, after reserving itself the right to full constitutional review of acts of community organs in the beginning, ${ }^{134}$ the German Court has developed an equal protection doctrine, according to which it only guards the legitimacy of the system as a whole, but does not control for the constitutionality of each individual act.

This conditional supremacy of community law has two dimensions. In principle, the Bundesverfassungsgericht accepts that political decisions of the EU institutions, in particular EU secondary legislation, are superior to domestic law. In its Maastricht decision, the Court pointed out that delegating ultimate decision-making authority to the European Union did not infringe upon the democracy principle contained in the German constitution. ${ }^{135}$ In its reasoning the Court followed the cooperation paradigm. It did not examine whether the institutional design of the European Union was legitimate per se. It rather derived the legitimacy via a formal chain of legitimization retraceable to the German 'people'. ${ }^{136}$ The EU was considered legitimate because the German citizens could indirectly influence the EU decision-making process through two channels. On the one hand, they were able to elect a significant number of the members of the European Parliament, and, on the other hand, they could elect the German Government, which takes part in the decision-making process in the Council. ${ }^{137}$

This jurisprudence has been confirmed in the recent Lisbon judgment of the Constitutional Court. ${ }^{138}$ In this decision, the Court had to decide whether ratifying the Treaty of Lisbon ${ }^{139}$ amending the founding treaties of the European Union and the European Community was constitutional with regard to the German Grundgesetw. It held that it was basically possible to transfer sovereign power to the EU even if the supranational institutions have the

133 Case 26/62, V an Gend \& Loos [1963] ECR 1.

134 Solange I, n 70 above.

135 Cases 2 BvR 2134/92 and 2159/92, Maastricht Treaty, 89 Entscheidungen des Bundesverfassungsgerichts 155 (Federal Constitutional Court, 12 October 1994).

136 Id., 183-86.

137 For a critique of this reasoning, which focuses on the retraceability of decisions to the German citizenry and not on the soundness of the decision-making process as such, see Brun-Otto Bryde, 'Die bundesrepublikanische Volksdemokratie als Irrweg der Demokratietheorie' (1994) 5 Staatswissenschaften \& Staatspraxis 305; Joseph H.H. Weiler, 'Does Europe Need a Constitution? Demos, Telos and the German Maastricht Decision’ (1995) 1 ELJ 219.

138 Case 2 BvE 2/08, Lisbon Treaty [2009] 123 Entscheidungen des Bundesverfassungsgerichts 267 (Federal Constitutional Court, 30 June 2009). English translation at http://www.bundesverfassungsgericht.de.

139 Treaty of Lisbon amending the Treaty on European Union and the Treaty establishing the European Community, O.J. 2007/C 306/01 (13 December 2007). 
competency to shape politics within certain limits, ${ }^{140}$ and to accept the albeit conditional ${ }^{141}$ supremacy of community law. ${ }^{142}$ However, the Court demanded to increase the legitimacy of EU law-making by strengthening the position of the German parliament in the decisionmaking process. In certain areas, which are supposed to belong to the core competencies of German statehood, the German representative in the Council, the principal legislative organ of the EU, is only allowed to act if he is backed by a formal authorization of the German parliament. ${ }^{143}$

The second dimension concerns the constitutional review of community legislation. The ECJ argues that European primary law is the exclusive standard of review for community acts. ${ }^{144}$ The Federal Constitutional Court has generally accepted this stipulation, as long as the ECJ guarantees by its jurisprudence that the effectiveness of the human rights protection under the EU treaty is comparable to that under the German constitution. ${ }^{145}$ The Court has confirmed this position in later judgments, where it held that two applications for constitutional review were inadmissible because the applicant had failed to show that the human rights protection by the ECJ lacked effectiveness. ${ }^{146}$

Contrary to the Maastricht decision, the Federal Constitutional Court does not try to derive the legitimacy of the ECJ decisions from domestic concepts and institutions, but concentrates on the supranational institution itself. In this context, the jurisprudence of the Court is thus close to the internationalist paradigm. It adopts a substantive standard of legitimacy. The decisive yardstick is the effectiveness of the human rights protection by the ECJ. The formal supremacy of the ECJ seems to be acceptable to the German Court because there is a considerable amount of material convergence in the human rights understanding of both courts so that fundamental conflicts are unlikely. ${ }^{147}$

While these judgments all refer to community law, in the European arrest warrant case, the Constitutional Court had to decide on the effect of framework decisions issued under the third pillar on Police and Judicial Cooperation in Criminal Matters. ${ }^{148}$ In this case, the German parliament had issued a European Arrest Warrant Act, implementing a framework decision of the European Union establishing the European Arrest Warrant ${ }^{149}$. The Constitutional Court held that the German statute violated two fundamental rights of the German Constitution - the right of German citizens not to be extradited and the right to judicial review.

140 Lisbon Treaty, n 138 aove, para. 237.

141 Cf. $i d$., para. 240 (stating that the limits of supremacy were ultra-vires-acts of EU institutions and such acts that infringe upon the unalterable core guarantees of the German constitution).

142 Id., para. 331.

143 Id., paras. 319, 365-66, 369, 388, 400, 413.

144 Case 11/70, Internationale Handelsgesellschaft [1970] ECR 1125.

145 Case 2 BvR 197/83, Solange II [1986] 73 Entscheidungen des Bundesverfassungsgerichts 339 (Federal Constitutional Court, 22 October 1986).

146 Cases 2 BvR 1210/98, Alcan [2000] Neue Juristische Wochenschrift 2015 (Federal Constitutional Court, 17 February 2000) and 2 BvL 1/97, EC Regulation on Bananas [2000] 102 Entscheidungen des Bundesverfassungsgerichts 147 (Federal Constitutional Court, 7 June 2000). English translation at http://www.bundesverfassungsgericht.de.

147 See Rosenfeld, n 10 above, 424.

148 Case 2 BvR 2236/04, European Arrest Warrant [2005] 113 Entscheidungen des Bundesverfassungsgerichts 273 (Federal Constitutional Court, 18 July 2005). English translation at http://www.bundesverfassungsgericht.de.

149 Council Framework Decision 2002/584/JHA (13 June 2002). 
However, at first glance, the Court did not challenge the supremacy of EU law. It only critiqued that the German legislature did not utilize the range of implementation attributed by the European decision. ${ }^{150}$ If it had done so, there would have been no violation of fundamental rights. ${ }^{151}$ This reasoning implicitly respects the primacy of the framework decision because otherwise it would not have been necessary for the court to examine whether there is a range of implementation. It could have fully reviewed the German statute without considering the range of determination by the European decision.

However, upon close reading, we find an unharmonious undertone in an obiter dictum of the decision. The Constitutional Court detects a democracy deficit in the third pillar because the European Parliament is not actively involved in the legislative process of the Police and Judicial Cooperation in Criminal Matters. ${ }^{152}$ The Court resolves this deficit by attributing a right to politically redesign the framework decision in the implementation process to the national parliaments. ${ }^{153}$ According to the Court, they are allowed fully to deny implementation, although such a right to denial cannot be found in the text of the treaty.

This position could be aligned with an internationalist reading, as the Court seems to be concerned with the legitimacy of the EU legislative process. However, the Bundesverfassungsgericht does not engage in a thorough examination of the latter - it only makes a brief statement. What really seems to be important to the Court is that the national parliament keeps its ability for political structuring in the absence of a significant German influence in the supranational decision-making process.

The jurisprudence of the Constitutional Court thus shows traces of both, the internationalist and the cooperation perspective. While the Maastricht decision and the case on the European Arrest Warrant can best be read in a cooperationist way, the Court seems to be willing to give up this position with respect to fundamental rights protection. Here, the Federal Constitutional Court does not abstain from any control, but this control only refers to the effectiveness of European human rights protection as such.

\section{The position vis-à-vis international courts outside the European Union}

The situation is different with regard to decisions of international tribunals outside the European Union, such as the European Court of Human Rights or the International Court of Justice. The German Constitutional Court has pointed out in two recent judgments that it does not privilege decisions of international tribunals with the restricted review standard of the 'equal protection' doctrine that it applies in the context of the European Union. Rather, it reserves itself the right to make a full constitutional review.

In general, the status of international treaties and the effect of decisions of international tribunals thereon are not explicitly stated in the German basic law. The Constitutional law doctrine in Germany opines that international treaties have no direct effect, but need to be transformed into domestic law. ${ }^{154}$ However, it is assumed that this transformation is

\footnotetext{
150 European Arrest Warrant, n 148 above, paras. 80, 94 \& 96.

151 See Nicolas Nohlen, 'Germany: The European Arrest Warrant Case' (2008) 6 I.CON 153, 158.

152 European Arrest Warrant, n 148 above, paras. 81.

$153 \mathrm{Id}$.

154 Christoph Engel, Völkerrecht als Tatbestandsmerkmal deutscher Normen 25 (1989); Ondolf Rojahn, 'Art. 59' in Ingo von Münch \& Philip Kunig (eds) Grundgesetz-Kommentar (Munich: Beck, 5th ed. 2001), para. 37.
} 
performed by the act that empowers the executive to ratify the treaty. ${ }^{155}$ If a treaty thus requires parliamentary ratification, then the approval of the treaty by the German parliament is considered to be the statute that transforms the treaty into German domestic law. The treaty then has the same status in domestic law as the transformatory act, hence usually that of a normal statute. It does thus not automatically trump contradicting statutes or even constitutional provisions. Rather, any conflict has to be solved according to the general rules on norm conflicts, like lex specialis or lex posterior. However, the German constitutional court has developed a principle that every statute has to be interpreted in accordance with international law as long as there is room for interpretation (Völkerrechtsfreundliche Auslegung). ${ }^{156}$

In the Görgülü decision, the Federal Constitutional Court held that decisions of the ECtHR were binding on domestic courts, but that this binding effect was not unconditional. ${ }^{157}$ The applicant in this case was a father, whose son was living with foster parents and who had been denied to see his child on a regular basis by the competent Regional Court of Appeal. Upon complaint, the ECtHR decided that the decision of the German court was contrary to the provisions of the ECHR. ${ }^{158}$ However, the Regional Court of Appeal upheld its decision and argued that the judgment of the ECtHR had no direct effect in the domestic legal order and was thus not binding for the individual courts. ${ }^{159}$

In the constitutional complaint procedure, the Federal Constitutional Court held that domestic courts were not bound to apply judgments of the ECtHR unconditionally. It argued that domestic courts had to deal with multipolar fundamental rights situation and that they were obliged to find a sensitive balance between the competing rights and interests. As not all parties to the domestic proceedings were also represented before the ECtHR, the judgment of the latter could not be transplanted into the German legal order without potential modifications. ${ }^{160}$

However, this does not mean that judgments of the ECtHR are not binding for the German courts. Rather, they have to take judgments, which establish a violation of the ECHR by Germany, into due consideration. ${ }^{161}$ If they want to deviate, they have to justify understandably why they do not follow the precedent of the ECtHR. In the case at hand, the Constitutional Court found that the Regional Court of Appeal had not taken the argumentation of the ECtHR into account and thus violated the rule of law principle of the German Constitution. ${ }^{162}$

155 Ingolf Pernice, 'Art. 59’ in Horst Dreier (ed) Grundgesetz. (Tübingen: Mohr Siebeck, 2nd ed. 2006), paras. 46-47.

156 Case 2 BvR 589/79 Unschuldsvermutung [1987] 74 Entscheidungen des Bundesverfassungsgerichts 358, 370 (Federal Constitutional Court, 26 March 1987).

157 Case 2 BvR 1481/04, Görgülü [2004] 111 Entscheidungen des Bundesverfassungsgerichts 307 (Federal Constitutional Court, 14 October 2004). An English translation is available at http://www.bverfg.de.

158 Case 74969/01, Görgülü v. Germany [2004] 31 Europäische Grundrechte Zeitschrift 700 (European Court of Human Rights, 26 February 2004).

159 Case 14 WF 64/04 [2004] Zeitschrift für Familienrecht 510 (Regional Court of Appeal Naumburg, 30 June 2004).

160 Görgülu, n 157 above, para. 50.

161 Id.

162 Id., para. 67. 
In the second decision ${ }^{163}$, the effect of the interpretation of treaty provisions by the ICJ was at stake. The occasion of the procedure was a decision of the German Federal Court of Justice (Bundesgerichtshof), ${ }^{164}$ in which the Court had interpreted Art. 36 of the Vienna Convention of Consular Relations in a different way than the ICJ in its LaGrand decision ${ }^{165}$. The applicant in the case before the German constitutional court was a Turkish national who had been arrested without having been informed of his right to notify the Turkish consular representation about his arrest stemming from Art. 36 (1) lit. b of the Vienna Convention on Consular Relations. ${ }^{166}$ He was later convicted because of the allegations that he had made to the police officer that interviewed him after his arrest. He asked for a review of his decision, but the Federal Court of Criminal Justice denied relief because the protection of a foreign national was, in his view, sufficiently guaranteed by his right to consult an attorney. Against this judgment the applicant filed an application to the Constitutional Court, which finally overturned the decision.

The Court finds that the decision of the Supreme Court had violated the right to a fair procedure guaranteed by the German constitution. Because of the principle of international law-friendly interpretation, the right to a fair procedure has to be interpreted in light of Art. 36 of the Vienna Convention of Consular Relations. ${ }^{167}$ In order to avoid future determinations by an international tribunal that the Convention has been violated, international treaty norms have to be interpreted in accordance with the jurisprudence of the competent court even if the judgments are not directly binding for the Federal Republic of Germany. ${ }^{168}$ As the Supreme Court had not respected the argumentation of the International Court of Justice in the LaGrand Case, it had thus violated the right to a fair procedure. ${ }^{169}$

However, the Constitutional Court again did not establish an unconditional obligation to comply with judgments of international tribunals. Remanding the case to the Federal Court of Criminal Justice, it did not order the latter to apply Art. 36 of the Vienna Convention without exception. Rather, it demanded to balance the guarantee set forth by the Convention against competing principles within the rule of law, such as procedural efficiency. ${ }^{170}$ The Constitutional Court thus confirms its Görgülü decision by leaving the opportunity to deviate from judgments of international courts, in particular if there are competing constitutional principles.

With this reasoning, the German Bundesverfassungsgericht follows the cooperation paradigm. ${ }^{171}$ On the one hand, it acknowledges that decisions of international institutions may have a direct effect in the domestic legal order. However, this effect is not unconditional. The

163 Case 2 BvR 2115/01, [2007] Juristenzeitung 887 (German Constitutional Court, 19 September 2006).

164 Case 5 StR 116/01 [2002] Neue Zeitschrift für Strafrecht 168 (Federal Court of Justice, 7 November 2001).

165 See $\mathrm{n} 45$ above.

166 n 44 above.

167 Case 2 BvR 2115/01, n 163 above, at 888.

168 Id., at 889.

169 Id., at 890 .

$170 \mathrm{Id}$.

171 Cf. also Andreas L. Paulus, 'The Emergence of the International Community and the Divide between International and Domestic Law' in The Divide between National and International Law, n 10 above, 216, 243-45 (describing the relationship of the German Constitutional Court and the international tribunals, such as the ECtHR and the ICJ, as a cooperational relationship). 
Court rather reserves a right to control every individual decision on its compatibility with the German constitutional order. ${ }^{172}$ This control is, on the other hand, a substantive, not a procedural one. The German Court thus wants to remain, at least on the face, in full substantive control of the implementation of international decisions into the domestic legal order.

To be sure, the court does not require the German citizens to have an indirect influence in the international decision-making procedure as it requires for the case of the European Union. This, however, is due to the nature of judicial decisions, which are not subject to political participation. The German court tries to balance this perceived deficiency by imposing an ex-post-control. Unlike in the case of the US Supreme Court, this ex-postcontrol is not exerted by the legislature, but it is the Court itself that controls the implementation of the international judgments.

\section{Evaluation}

Although not being entirely homogenous, the jurisprudence of the Bundesverfassungsgericht basically follows the cooperation paradigm. This is most obvious with regard to the implementation of judgments of international tribunals, like the ECtHR or the ICJ. Here, the Constitutional Court acknowledges that such decisions may have a direct effect in the domestic order. However, they stand under the proviso of a substantive control by the German Court. In the context of the European Union, the Court meanders at times between the internationalist and the cooperation paradigm. In particular with regard to fundamental rights, it basically accepts the jurisprudence of the ECJ, refraining from further substantive control. However, this internationalist approach is probably due to the special nature of the European Union. Not having accepted the - albeit conditional supremacy the ECJ jurisprudence would have provoked major conflicts and endangered the whole integration process. ${ }^{173}$ Furthermore, judgments like the Maastricht decision reveal the rather cooperationist mind-set of the German Court because the reason for accepting the supremacy of EU law is not the legitimacy of the institutional design of the EU as such, but is derived from the indirect participation of the German people in the legislative process.

\section{New perspectives on the monism-dualism-dichotomy}

The coordination of different legal systems has become a complex issue that cannot easily be integrated into the old monism-dualism-dichotomy. ${ }^{174}$ The international legal order has moved away from being one monolithic system. Rather, we observe the emergence of a certain heteronomy of international tribunals and institutions varying in the extent of their competences and the design of their decision-making procedures. The reception of decisions of these institutions by national legal orders cannot be subject to a one-fits-all approach. Rather, the task of domestic constitutional judges has become more complex. When determining the status of international secondary law, judges cannot solely rely on formal legal norms, but also have to take political considerations, particularly the legitimacy

172 Cf. Krisch, n 10 above, at 197 (noting that this control strategy is common among European constitutional courts).

173 Frank Schorkopf, Grundgesetz und Überstaatlichkeit (2007) 150.

174 Accord Nijman \& Nollkaemper, n 10 above, at 341; Paulus, n 171 above, at 217. 
of the external legal order, into account. Instead of distinguishing monist from dualist legal orders, we should thus rather focus on the strategy a constitutional court chooses in order to cope with this challenge. This contribution has identified three different approaches - a state sovereignty centered, a cooperation based, and an internationalist perspective.

This distinction is at odds with the traditional monism-dualism-dichotomy. Even an internationalist approach does not imply a monist perspective. Monism would require an unconditional acceptance of decisions of international institutions - an approach that was followed by the European Court of First Instance in the Kadi and Yusuf decisions. ${ }^{175}$ In contrast, although qualified as internationalist here, the ECJ is certainly not a monist court. ${ }^{176}$ But this is precisely the point. Under the traditional distinction, the approaches of all three examined courts would be qualified as dualist, although there are significant differences between the reasoning of the US Supreme Court and the reasoning of the European Court of Justice. ${ }^{177}$ It is these differences that the classification proposed in this contribution tries to capture.

How do we explain the differences in the national jurisprudence? A positivist will be inclined to trace them back to the different texts of the relevant constitutional provisions. But neither the German constitution nor the EC treaty tell us very much about the domestic effect of international treaties. And an unprejudiced glance at Art. VI para. 2 of the American constitution would probably have suggested a much more internationalist position than the one developed by the U.S. Supreme Court in Medellin. Furthermore, a positivist perspective cannot explain why certain courts are not uniform in treating international decisions. The ECJ, e.g., readily accepts the conditional supremacy of judgments of the European Court of Human Rights (ECtHR) on the interpretation of human rights. On the other hand, it challenged the applicability of a UN Security Council resolution in the Kadi case.

The explanation, therefore, has to be a different one. In particular, one reason is worth to be explored. The variation in the jurisprudence can be due to a different level of trust into international institutions. ${ }^{178}$ The more the international decision-making procedures embrace the rule of law, the more the trust in these procedures will be enhanced. Formal guarantees are not everything, though. The performance of a decision-making procedure equally depends on the mind-set of the actors operating within this procedure. ${ }^{179}$ The extent to which a constitutional court places trust in the actors involved in international procedures also depends on the own cultural predetermination. ${ }^{180}$ Judges with an international perspective and a greater exposure to international cooperation will probably

\footnotetext{
175 See n 116 above.

176 This is underlined by the recent Intertanko decision of the Court. See Case C-308/06, Intertanko [2008] ECR I-4057.

177 But see Christian Tomuschat, 'The Kadi Case: What relationship is there between the Universal Legal Order under the Auspices of the United Nations and the EU Legal Order?' (2009) 28 YEL 654, 662 (seeing close resemblances between both decisions).

178 See Joseph H.H. Weiler, The Constitution of Europe (1999) 318.

179 It is thus not without reason that the literature on democratization focuses on trust as an important factor in order to enhance democratization processes. See Charles Tilly, Trust and Rule (2005) 132-37.

180 See Paul W. Kahn, 'American Hegemony and International Law' (2000) 1 Chicago JIL 1, 17 (claiming that the American narrative of popular sovereignty makes some American constitutional lawyers suspect to decisions taken outside the national realm). See also Krisch, n 10 above, at 212 for the observation that national judges have often internalized the values of their own legal system to such an extent that they consider them to be superior to foreign solutions.
} 
put more trust into international decision-making procedures than judges coming from a more isolationist tradition.

However, different conceptions of legitimacy cannot fully explain the positions of constitutional courts that we observe. In some cases, strategic considerations and the exigencies of the political framework play a crucial role. On the one hand, they may be one of the reasons why courts adopt a certain conception of legitimacy. This would, e.g., explain why the German Constitutional Court adopts a different attitude towards the human rights jurisprudence of the ECJ than towards judgments of the ECtHR or the ICJ. The United States, in contrast, are not involved in a dense network of international integration so that the US Supreme Court can take a more reserved perspective with regard to the implementation of international law. ${ }^{181}$ On the other hand, strategic concerns may, at times, even override legitimacy considerations. This can best be observed at the jurisprudence of the ECJ vis-à-vis the direct effect of decisions of the WTO Appellate Body. Here, the reasoning of the court is clearly framed in strategic terms without paying much attention to the legitimacy of the WTO system.

Both of these factors are probably contributing to the development that we observe in the field of coordinating international and domestic law. From both perspectives, it is no surprise that the ECJ, which is a hybrid body somewhere in between a constitutional court and an international tribunal itself, takes the most internationalist stance of the three examined courts. But even the internationalist perspective does not require an unconditional supremacy of international law. This is expressed by the Kadi judgment, where the Court dismissed a U.N. sanctions system that does not even come close to resembling a procedure guided by the rule of law. The ECJ followed a prudent strategy addressing signals to two different kinds of actors. With regard to the international system, it did not close the door, but entered into an institutional dialogue by leaving open the opportunity of accepting a revised sanctioning system in the future. ${ }^{182}$ Concerning the Constitutional courts of the EU member states, the ECJ took one important step in order to strengthen their trust in its adherence to fundamental rights and the rule of law. ${ }^{183}$

181 Benvenisti, n 11 above, 242. However, this development comes at a price. There is evidence that the influence of the US Supreme Court on other constitutional courts is decreasing. See Adam Liptak, 'U.S. Court Is Now Guiding Fewer Nations', New York Times (18 September 2008).

182 Similarly Jean d'Aspremont \& Frédéric Dopagne, 'Kadi: The ECJ's Reminder of the Elementary Divide between Legal Orders' (2008) 5 IOLR 371, 377-78; André Nollkaemper, 'Rethinking the Supremacy of International Law' (2010) 65 Zeitschrift für Öffentliches Recht 65, 84-85 (all arguing that the Kadi case may put pressure on the Security Council to bring ist procedures in conformity with human rights standards). Contra Andrea Gattini, 'Case Comment' (2009) 46 CMLR 213, 226-27; de Búrca, n 127 above, 58-59 (both criticizing that the ECJ did not enter into a dialogue with other actors in the international arena). Gattini claims that the Court should have sought the solution by analyzing the legality of the U.N. Security Council resolutions under international law, in particular ius cogens. However, ius cogens alone may not provide us with sufficient standards in order to examine the legitimacy of the actions of the U.N. Security Council.

183 Accord Heiko Sauer, 'Rechtsschutz gegen völkerrechtsdeterminiertes Gemeinschaftsrecht? (2008) 61 Neue Juristische Wochenschrift 3685, 3687. See also Takis Tridimas and Jose A. Gutierrez-Fons, 'EU Law, International Law, and Economic Sanctions against Terrorism: The Judiciary in Distress?' (2009) 32 Fordham ILJ 660, 728 (arguing that the approach of the ECJ strengthened the internal legitimacy vis-à-vis the citizens). 